\title{
Septa, septal traces and septal filaments in the foraminiferal genus Nummulites Lamarck
}

\author{
C. GEOFFREY ADAMS \\ Department of Palaeontology, British Museum (Natural History). \\ Cromwell Road. London SW7 5BD
}

\begin{abstract}
Several critical morphological features for the discrimination of Nummulites species are discussed and redefined, and three orders of septal filament are distinguished. A change in mode of growth, following the loss of the marginal cord in the adult stages of some species, is described.
\end{abstract}

\section{INTRODUCTION}

Few genera of the Foraminifera include more nominal species or have been more intensively studied than Nummulites, the subject of innumerable publications during the last 150 years. Yet despite this attention. the definitions of three critical morphological terms: septa. septal filaments and septal traces have remained ambiguous. Confusion has arisen because the original definition of "septal filament" (d'Archiac \& Haime. 1853). was based on structures observed in specimens referred to the species group to which $N$. laevigatus (Bruguière), the type species, and $N$. britannicus Hantken belong. Unfortunately, these species and their immediate relatives possess septal filaments that are atypical of the genus as a whole.

Further confusion has occurred because septal filaments in many of the larger species have been described as "meandrine" (see PI. 1. fig. 6: Pl. 4. figs. $6,7)$, but without any clear indication of the real meaning of this term, or of its implications for the growth of the shell. Finally, many authors have failed to distinguish between filaments and filament traces. The purpose of this paper is, therefore, to clarify the relevant terminology, to redescribe and re-evaluate certain basic morphological characters, and to point out that growth, in the adult stages of individuals in some lineages, is not necessarily effected simply by adding new chambers in the equatorial plane.

\section{TERMINOLOGY}

All species of Nummulites possess planispirally coiled tests comprising numerous chambers (Figs. 1. 2). The partitions separating the chambers in each whorl are called septa (Fig. 2a), and the visible expression of a septum on the outer surface of the shell is termed a septal trace (Fig. 1a). In the simpler species, in which broad category all primitive forms are included. the septa are continued - as septal filaments - over the lateral surfaces of the test until they meet at the poles (Fig. 1a) or terminate against polar pillars (Pl. 1. fig. 4).
Septal and primary filament traces, either separately or in combination, are homologous with "sutures" in other groups of foraminifera. Unfortunately, in many species. septal filaments are not filamentous. and the reason for the apparently unnecessary and undesirable terminological change (septum to septal filament) can be understood only by reference to Carpenter's redescription (1849) of $N$. laevigatus (actually $N$. britannicus) which species is, unfortunately, neither simple nor striate. Primary filaments and filament traces may be almost straight, or weakly to strongly curved. Since filaments normally converge towards the poles. it follows that each chamber is widest at the test margin and narrowest at the centre (Fig. 1a). In species such as $N$. variolarius Lamarck and $N$. vascus Joly \& Leymerie, the main lumen of the chamber (i.e. the space immediately below the marginal cord) is continued over each lateral surface as an alar prolongation (Fig. 2b). The main lumen, together with those of the alar prolongations, constitutes the spiral cavity. In these species, the number of septal filaments equals the number of septa, whereas in the reticulate and subreticulate groups, filaments - in the B generation at least - are always more numerous than septa.

Successive chambers are connected by basal intercameral foramina (Fig. 2a) which form by resorption as new chambers are added. There is normally no primary aperture ( $\mathrm{Pl}$. 3, figs. 1b, c, 2), its function being assumed by the canal system in the marginal cord, as in Heterostegina depressa d'Orbigny (Röttger et al., 1984). The general morphology of the penultimate and last chambers in Nummulites has been illustrated by Blondeau (1972, fig. 17); Hottinger (1977) has illustrated the canal system.

$N$. vascus Joly \& Leymerie. $N$. discorbinus (Schlotheim) and Nummulites variolarius (Lamarck) are typical examples of simple forms of the genus (PI. 1, figs. $1-3)$. These radiate $(=$ striate $)$ species, possess septal filaments which run inwards towards the umbo, 
thus resembling spokes in a wheel. their traces appearing on the surface of the test as straight or curved lines marking the chamber junctions (Fig. 1a).

In all striate species, the septal filaments and septal traces necessarily become crowded towards the poles (Pl. 1, figs. 1-5), where they may terminate against a central pillar (P1. 1, fig. 4) or group of pillars. There must clearly be a limit to the number of alar prolongations able to reach the centre, and once this is reached
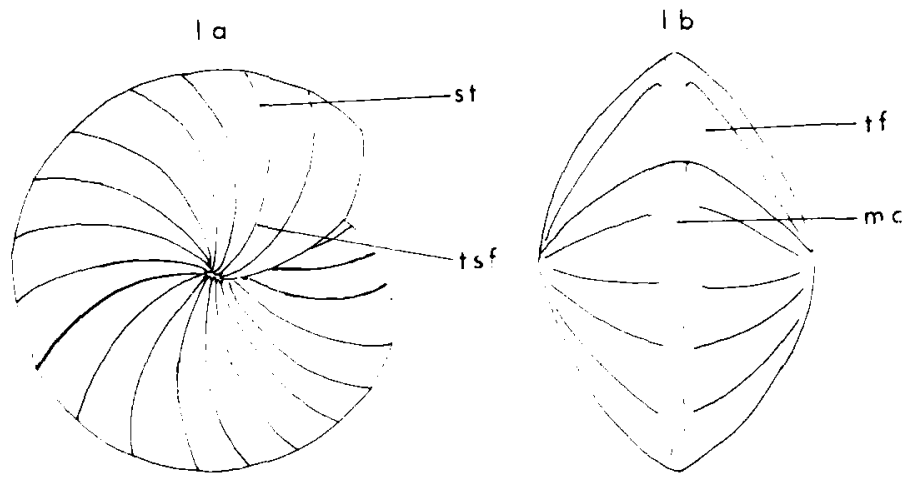

Fig. 1a, b. Lateral (a) and edge (b) views of a striate species showing septal traces (st), traces of septal filaments (tsf), the chevron-shaped terminal face (tf), and the marginal cord (mc). In this individual the septal filaments are merely extensions of the septa. Schematic. the simple radiate pattern of septal filaments can no longer be maintained. In a few species (e.g. $N$. planulatus Lamarck), some septal filaments terminate to one side of. or beyond, the centre, thus producing slightly more complex surface patterns ( $\mathrm{Pl}$. 4. figs. 2 , 3). In others, overcrowding is avoided by the sharp backward curvature of a few filaments before reaching the pole. This causes them to terminate against previously formed filaments and produces short alar prolongations which leave sufficient space for the next few chambers to form normally (Fig. 3a). Polar crowding is not, however, necessarily the cause of the strong septal curvature which reduces chamber length radially, since some species, e.g. $N$. discorbinus (Pl. 1, fig. 2), possess numerous closely spaced septa and septal filaments, relatively few of which are substantially shortened. The apparent tendency for septal filaments in some species to twist together at the centre is an optical illusion produced by the sharp backward curvature of a few long filaments near the pole. Nevertheless, as the size of the test increases and more septa are produced at the periphery (as must occur if chambers are not to elongate progressively), the number of filaments curving sharply backwards and terminating against those formed previously (Fig. 3b) usually increases. This is illustrated by $N$. incrassatus de lá Harpe (Pl. 1, fig. 4), N. beaumonti d'Archiac \& Haime (Pl. 1, fig. 5), and $N$. gizehensis (Forskal).

\section{Explanation of Plate 1}

Fig. 1. Nummulites vascus Joly \& Leymerie. Megalospheric form showing several short chambers, simple, curved primary septal filaments. Septal traces not visible $(\times 15)$. Lower Oligocene, Biarritz, France. P52160.

Fig. 2. Nummulites discorbinus (Schlotheim). Microspheric form, side view, showing simple, curved, primary septal filaments, crowded towards the centre $(\times 8)$. Middle Eocene. Ras Awainat Ali, Jebel Dukhan, Qatar. P52161.

Fig. 3. Nummulites variolarius (Lamarck). Megalospheric form, side view, showing primary septal filament traces (= sutures in other groups of foraminifera) $(\times 9)$. Whitecliff Bay, Isle of Wight. P52162.

Fig. 4. $N$. incrassatus de la Harpe. Microspheric form showing irregular polar pustule and simple septal and septal filament traces $(\times 20)$. Lower Oligocene, Sangonini, Vicenza, Italy. P52163.

Fig. 5. N. beaumonti d'Archiac \& Haime. Microspheric individual showing polar crowding of septal filaments $(\times 5)$. Middle Eocene. Gebel-el-Rus, Western Desert, Egypt. P52164.

Fig. 6. N. gizehensis (Forskal). Dissected microspheric form showing strongly curved, subparallel groups of primary septal filaments. Closely spaced septa visible in last 8 whorls $(\times 3.5)$. Middle Eocene, Cairo, Egypt. P52165.

Fig 7. N. britannicus Hantken. Dissected microspheric form showing septa and septal filaments $(\times 5)$. Middle Eocene, Bracklesham Bay, Sussex. P52166. See also Pl. 2, fig. 4.

Fig. 8. N. britannicus Hantken. Double rows of trabecular pores on outer side of spiral sheet (lateral surface) $(\times 80)$. East Beach, Selsey, Sussex. P52167.

Fig. 9. $N$. brongniarti d'Archiac \& Haime. Dissected microspheric form showing complex arrangement of septal filaments in central area and thickened marginal cord of outermost $10-12$ whorls $(\times 5)$. Middle Eocene, Ronca, Italy. P52168.

Fig. 10. N. fichteli (Michelotti). Part of microspheric individual showing primary and secondary septal filaments of equal thickness $(\times 30)$. Compare with fig. 3. PI. 2. Oligocene, Kuh-i-Band-i-Bagh, Iraq. P52169. 


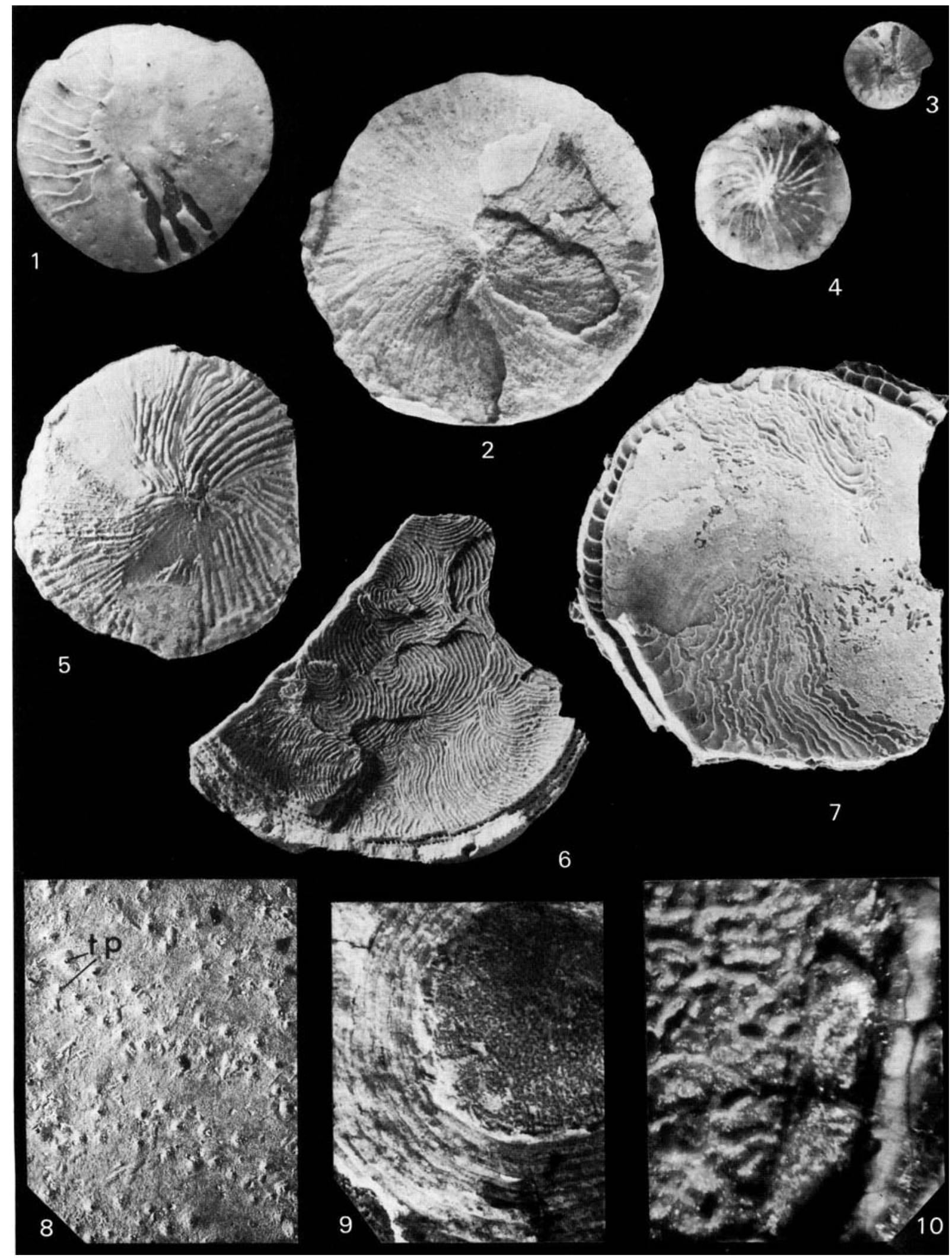


a

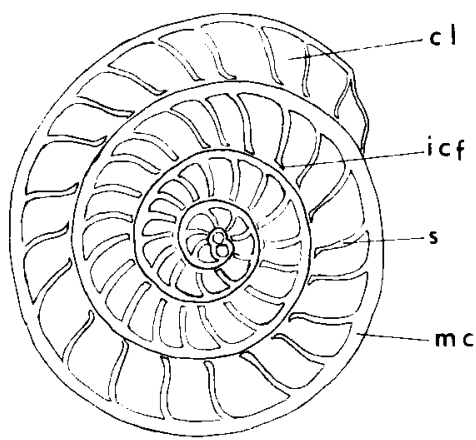

b

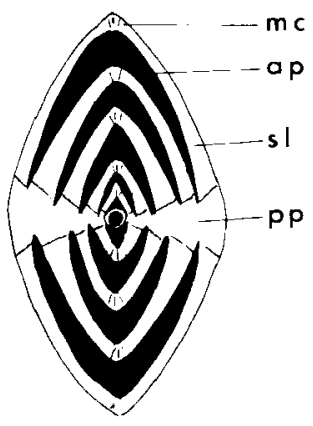

Fig. 2a, b. Equatorial and transverse sections of a striate species, showing alar prolongations (ap), chamber lumen (cl), intercameral foramina (icf), marginal cord (mc), polar pillar (pp), septa (s), and spiral lamina (sl). Based on $N$. variolarius.

Strongly recurved septal filaments in species such as $N$. gizehensis are commonly subparallel, their marked curvature allowing the alar prolongations to maintain an even width across the test (PI. 1, fig. 6). The highly complex spiral patterns illustrated by many authors, e.g. Rozlozsnik (1929, Pl. 4, figs. 15, 18) are mainly illusory, and result from simultaneous observations of filaments on two or more closely appressed, but abraded whorls, thus allowing them to appear as though on a single surface. Although often described as meandrine, individual filaments (Fig, 3b; Pl. 1, fig. 6; Pl. 4, figs. 6,7) never make more than one U-turn; anything more complicated than a single U- or S-bend (either separately or in combination) apparently being impossible. Off-centre terminations of filaments produce nodes (Pl. 4, figs. 2, 3); these, together with the presence of secondary filaments (see p. ) and the effects of surface abrasion are responsible for the complex "meandrine" filament patterns observed on many tests. Mode of growth (see below) is also important, since the presence of two or more growth centres will obviously introduce complexities, but as will be shown later, the most complex patterns are associated with the development of intercalary whorls and the loss of the marginal cord, phenomena restricted to a relatively small number of species.

The term "filet cloisonnaire" was introduced by d'Archiac \& Haime (1853, p. 51) who wrote: "la disposition des prolongements cloisonnaires que nous nommerons filets cloisonnaires et réseau cloisonnaires," (the arrangement of the septal extensions which we call septal filaments and septal network). They were referring to extensions of the septa previously described by Carpenter (1849) as "septal prolongations" on the basis of observations made mainly on $N$. laevigatus (actually $N$. britannicus Hantken). Their next few words, "places entre des lames" (situated between sheets) indicate that they were referring to the filaments themselves and not to their surface traces. This new term was subsequently applied to all nummulites, despite the fact that the terminal face (future septum) in simple species such as $N$. variolarius (Pl. 1 , fig. 3) must clearly be a single, slightly curved. chevron-shaped plate (PI. 3, figs. 1b, 2) bisected by the marginal cord, very different in appearance from that of the more complicated $N$. britannicus Hantken (compare Pl. 1, figs. 1-3 with Pl. 3, figs. 1d. 3a). D'Archiac's term "septal filament" is in some respects less appropriate than Carpenter's "septal prolongation", since relatively few septal extensions are truly filamentous. Many subsequent authors have failed to distinguish between septal filaments and their surface traces and have used filet cloisonnaire for both. Unfortunately, after well over a century and a quarter of use and misuse, the term "septal filament" is too well established to be abandoned. It can, however, be redefined and made more meaningful.

It is possible to recognise three basic orders or grades of septal filament (Fig. 4): (1) primary filaments, which are essentially Carpenter's septal prolongations since they represent continuations of the septa over the lateral surfaces of the test from the point where they touch the marginal cord of the previous whorl; (2) secondary filaments which, in the $N$. laevigatus group, comprise the distal walls of the blister-like chamberlets which form over the lateral surfaces of the test; and (3) tertiary filaments which originate from a spiral ridge along the line of the marginal cord (see Boussac, 1906b, pl. 1, figs. 1,2) and Fig. 5, or as short lateral spurs on either primary or secondary filaments. Primary filaments are present in all species, and are the only type present in simple striate forms. Secondary filaments

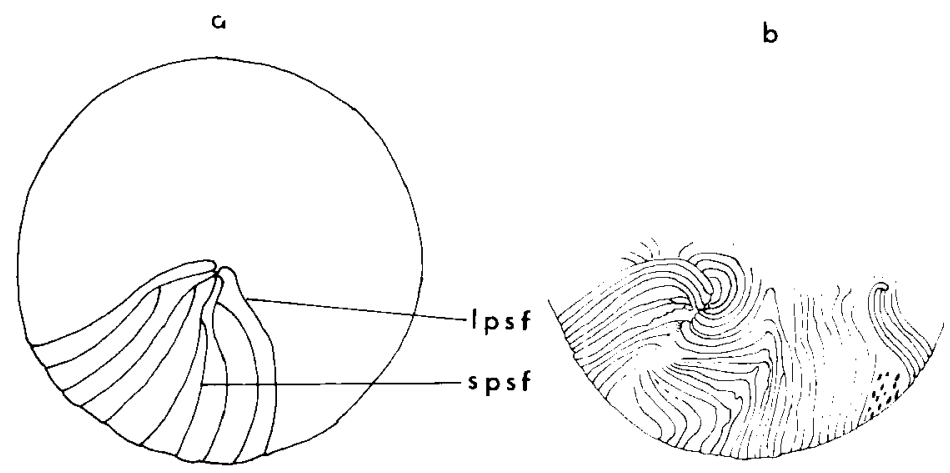

Fig. 3a, b. Schematic drawings showing strongly curved alar prolongations delimited by septal filaments: a, drawn from the striate species, $N$. atacicus; $b$, from the meandriform $N$. gizehensis; lpsf \& spsf = long and short primary septal filaments. 
occur mainly in the relatively small number of species which comprise the subreticulate and reticulate groups to which $N$. britannicus Hantken (Pl. 1, fig. 7; PI. 3, fig. 3a). N. brongniarti d'Archiac \& Haime (Pl. 4, figs. 1a, b), and $N$. fichteli (Michelotti) (Pl. 2, fig. 9) belong. In these groups, primary filaments tend to lose their individuality over the lateral surfaces of the test, often becoming truly thread-like as in N. britannicus (PI. 2, fig. 4). Septal filaments are most clearly visible on the undersides of the spiral laminae in the outer whorls of partially decorticated or broken specimens. In the $N$. laevigatus group, approximately half the filaments in adult individuals are continuations of the septa, the remainder being generated secondarily.

Filaments may be non-granulate (Pl. 1, figs. 1, 3-5) or granulate (PI. 2, figs. 1, 5, 7); like the septa themselves, they are canaliculate (PI. 3, fig. 4), and in well preserved individuals their traces are usually visible on the test surface.

Since septal and filament traces follow the paths of the underlying septa and septal filaments, it is not surprising that "septal filament" has often been interpreted as meaning both the internal continuation of a septum over the lateral surface (between the spiral laminae) and its expression on the test surface. Less understandable is the use of this term to describe the condition seen in species such as $N$. brongniarti, $N$. fichteli, and $N$. sublaevigatus d'Archiac, in all of which primary filaments are often indistinguishable, except at their points of origin, owing to the strong development of secondary and tertiary filaments.

Carpenter's drawing (1849, pl. 4, fig. 6) of the septal filaments in a specimen referred to $N$. laevigatus (Bruguière), but actually $N$. britannicus Hantken, from Bracklesham Bay, has been copied by many subsequent authors (e.g. Rozlozsnik, 1927; Blondeau, 1972; Schaub, 1981) and accepted as typical of nummulites with meandrine septal filaments. Unfortunately, the structures shown are characteristic only of the group of nummulites to which $N$. britannicus (see Carpenter, 1849, pl. 3, fig. 3) and N. laevigatus belong. As already noted, $N$. gizehensis is a well known "meandriform" species (PI. 1, fig. 6) yet it often lacks the secondary filaments characteristic of the $N$. laevigatus group.

The third grade of filament may be distinguished in the subreticulate lineages typified by $N$. laevigatus (Bruguière) and $N$. brongniarti d'Archiac \& Haime, and in reticulate species such as $N$. fabianii (Prever) and $N$. fichteli (Michelotti). All three types may be found in a single reticulate individual.

\section{INTERCALARY WHORLS AND REVERSALS}

Division (dedoublement) of the spire is a well known feature of both nummulites and assilines, and is responsible for the production of intercalary whorls. It is reflected in the name of one species. $N$. millecaput a

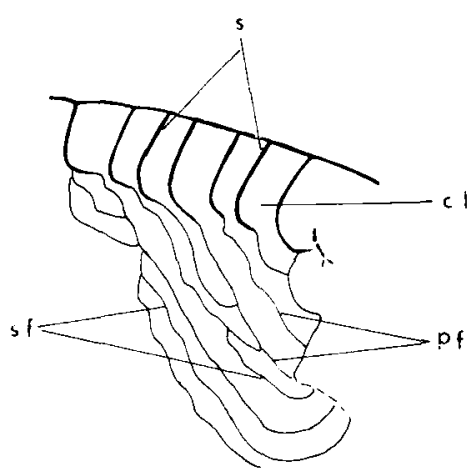

b

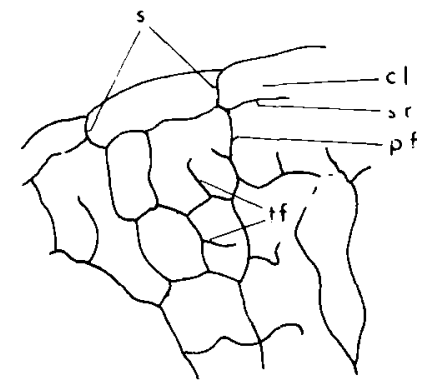

Fig. 4a, b. Schematic representations of septa and septal filaments in $N$. britannicus and $N$. fichteli; cl $=$ chamber lumen, $\mathrm{pf}=$ primary filament, $\mathrm{s}=$ septum, $\mathrm{sf}=$ secondary filament, $\mathrm{sr}=$ spiral ridge, tf $=$ tertiary filament. In the earlier reticulate nummulites, the spiral ridge is responsible for the majority of transverse connections (lames transverse of Boussac, 1906a, b) between the septal filaments.

Boubée - a reference to its many heads (growing points). The young intercalary spires usually grow in the same direction as their antecedents (Fig. 6a), but in a minority of specimens their direction of coiling may be reversed (Fig. 6b, c). Reversals may be of short duration, lasting only until the backward-growing whorl is overridden by the previous normal whorl, or may persist for several whorls. Good examples have been illustrated by Schaub (1981), and include representatives of $N$. distans Deshayes (Schaub, tab. 12g), N. maximus d'Archiac (Schaub, tab. 13c) and Assilina gigantea de la Harpe (Schaub, tab. 17a).

Intercalary whorls form by division (splitting) of the marginal cord (Fig. 6a), and when reversed are easily recognised because their septa incline in the opposite direction to those in normal whorls. But whichever direction (normal or reversed) a new spire takes, the marginal cord remains visible, and the septal filaments 
a

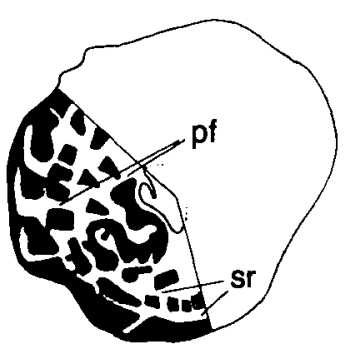

b

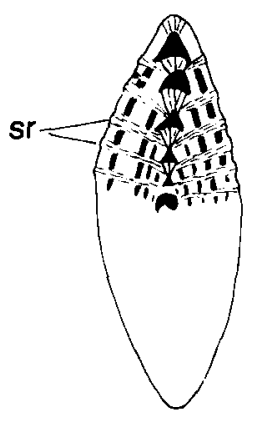

Fig. 5a, b. Slightly abraded surface of $N$. fabianii showing the reticulum. Primary filaments (pf), spiral ridge (sr).

stay confined to the lateral surfaces of the test. However, in a few of the species with tripartite spires, e.g. $N$. obtusus Sowerby, $N$. tavertetensis Reguant \& Clavell, and occasionally in $N$. perforatus (Montfort), the marginal cord is lost in the final growth stage, thus allowing strongly curved septal filaments to cross the peripheral margin (Pl. 4, fig. 9). Samanta (1981) drew attention to this phenomenon in $N$. obtusus and $N$. perforatus, and attributed the low height of the chambers in the third stage of growth to the introduction of intercalary whorls. This cannot, however, be wholly correct since such whorls also occur in earlier growth stages. Moreover, in N. millecaput and many other species, the chambers in the intercalary whorls quickly attain the same height as those in previous spires. The main reduction in chamber height seems to be caused by the loss of the thick marginal cord and its replacement by the thinner spiral sheet (Pl. 4, figs. 8 , 9), and by the substitution of low interfilamental spaces for high chamber cavities. The short reversals (Fig. 6e) sometimes seen in equatorial sections through the final growth stage are artefacts. They occur because the plane of section no longer bisects the septa in the last few whorls but cuts instead through septal filaments which now cross the periphery and may be aligned in any direction. The final growth stage is therefore characterised by the absence of a marginal cord and by the irregular length of the "pseudochambers" (interfilamental spaces) along the peripheral margin. Septa and septal filaments cease to be definable as distinct entities, and basal intercameral foramina are no longer visible in equatorial sections.

\section{MODE OF GROWTH AND WALL THICKNESS}

All striate species grow by the addition of chambers to the distal end of the planispiral coil. As each new chamber forms, a layer of calcite is deposited over the whole of the last whorl. This results, as Smout (1954) has shown, in the spiral lamina and marginal cord thickening backwards from the terminal chamber to the beginning of the penultimate whorl, and thereafter thinning gradually towards the embryonic apparatus (Fig. 2a). This is true for the early stages of growth of all species of Nummulites, but not for the adult stages of certain advanced forms.

In species with meandrine septal filaments, the spiral lamina becomes very thin in the adult stage, and no longer shows progressive thickening back through the last whorl. This seems to be because a complete layer of calcite is not necessarily deposited over the whole outer surface each time a new chamber forms, and because the development of intercalary whorls implies the existence of two or more growth centres. The spiral

\section{Explanation of Plate 2}

Figs. 1-6. N. britannicus Hantken. 1-5 are photographs of a single dissected microspheric individual (P52166): fig. 1, early stage of microspheric form $(\times 20)$ showing simple radiate septa, septal filaments, and granules (P52166a); fig. 2, more mature stage $(\times 8)$ showing septa, primary and secondary filaments, and lateral chamberlets; the septal filaments are narrower than the septa (P52166b); fig. 3, external appearance of growth stage represented by fig. $2(\times 8)$; fig. 4 , par of the inside of a later whorl $(\times 15)$ showing septa $(\mathrm{s})$, septal filaments $(\mathrm{pf}=$ primary, $\mathrm{sf}=$ secondary) and the funnel $(\mathrm{fn})$. See also Pl. 1, fig. 7; 5, abraded outer surface of the same test $(\times 4)$ showing septal filaments and granules; fig. 6a, b. N. britannicus. Early stage showing simple radiate septa $(\times 60)$. Compare fig. $6 \mathrm{a}$, b with figs. 1 and 8 ; fig. 6b, equatorial split through fig. 6a showing operculiniform growth in juvenile stage $(\times 60)$. P52170. All Eocene, Bracklesham Bay, Venables Collection.

Fig. 7. N. gizehensis (Forskal). Microspheric form at 4th whorl showing simple, granulate septal filaments and polar pillar $(\times 20)$. P52171.

Figs. 8a, b. N. britannicus Hantken. Megalospheric individual (lateral surfaces) showing that the last few chambers may become evolute in the adult stage. Probably a gerontic feature. Primary and secondary filaments are visible: fig. $8 \mathrm{~b}$, same individual, oil immersion ( $\times 6.5$ ). P52172. Middle Eocene, Southampton Dock, Hants.

Fig. 9. N. fichteli (Michelotti). B form. Split specimen $(\times 5)$ with centre dissected out to show complex filament pattern. For detail see Pl. 1, fig. 10. 

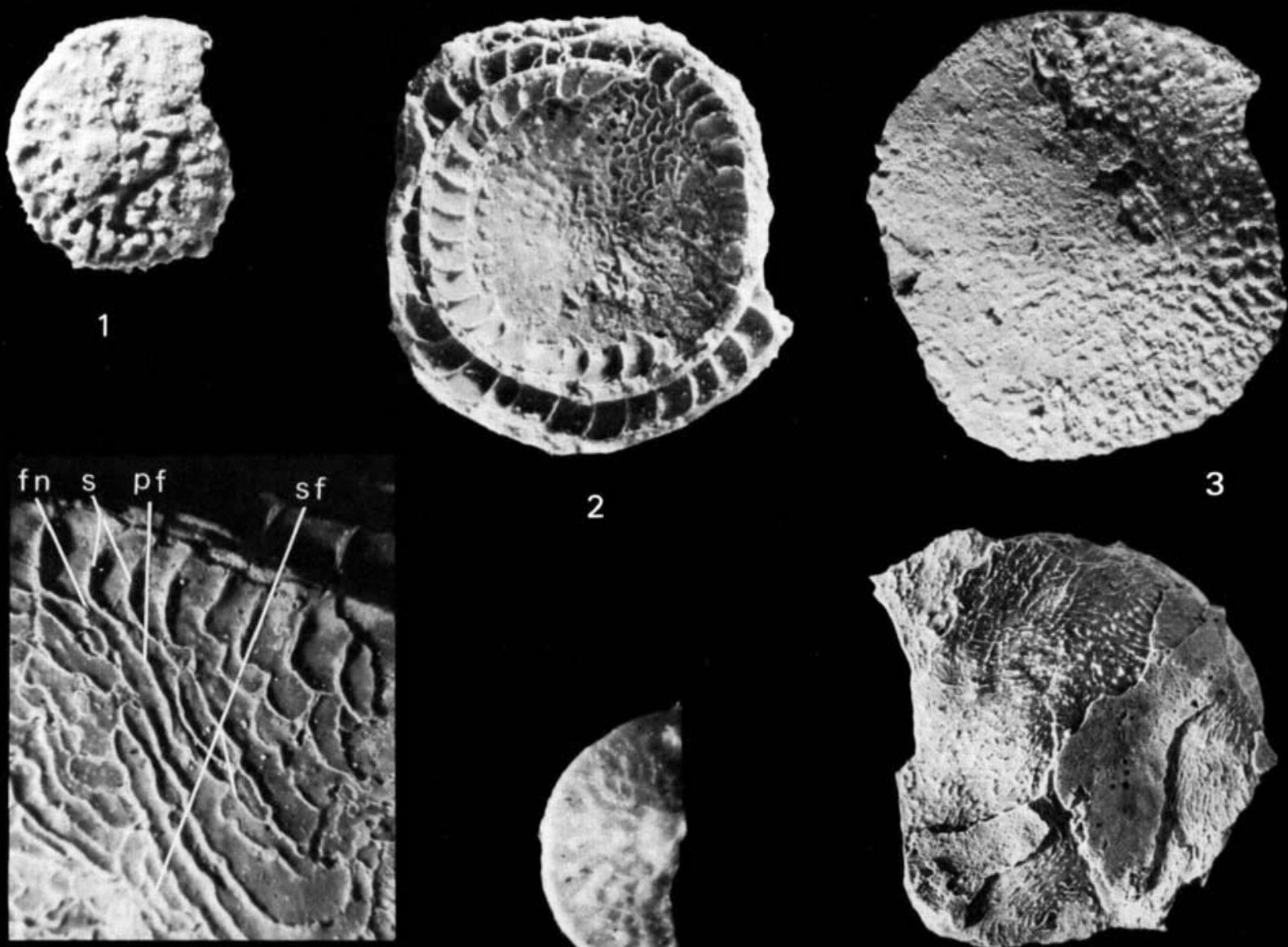

2

4

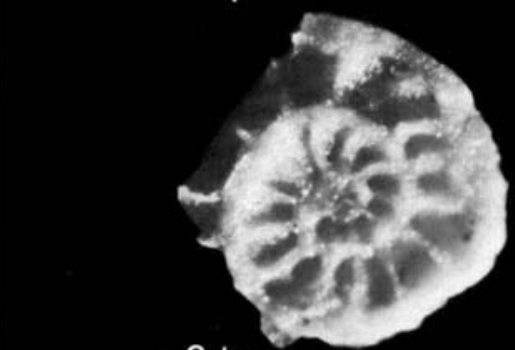

$6 \mathrm{~b}$

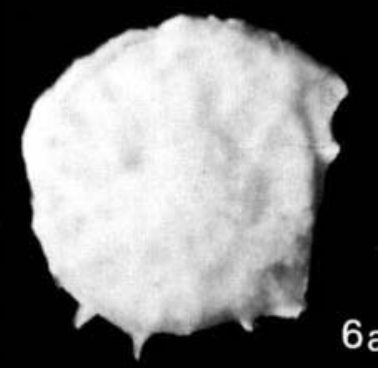

$6 a$

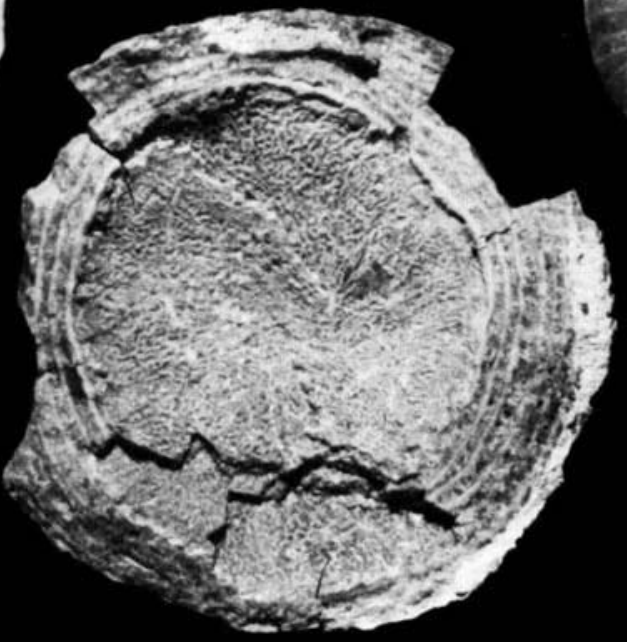

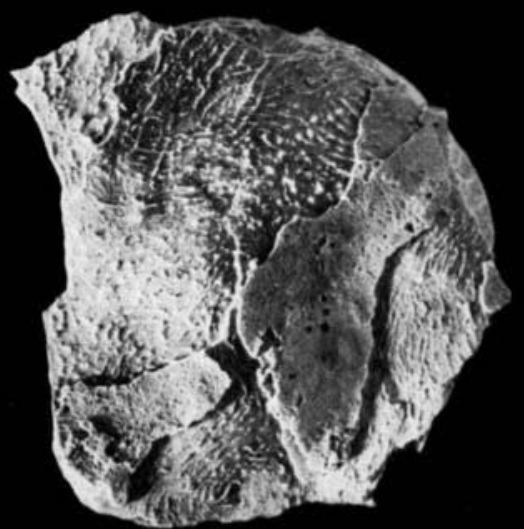

5

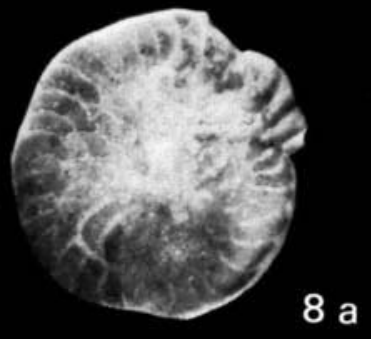

8 b

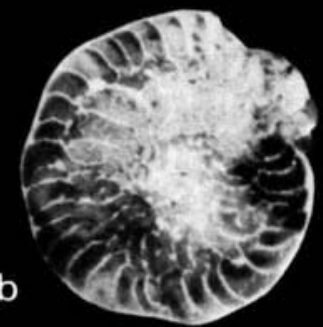


lamina therefore remains relatively thin or becomes irregularly thickened. All species with well developed meandrine septal filaments show some thinning of the spiral laminae in the adult stage. Since all gradations from striate to fully meandrine filaments occur within the genus, there are equivalent gradations in thickness of the spiral laminae.

Examination of well preserved, fully grown, specimens has shown that in some striate species, e.g. $N$ rectus Curry, and in the megalospheric forms (also striate) of subreticulate species such as $N$. laevigatus, there is a tendency for the last few chambers to be small, and for their alar prolongations not to extend far towards the centre of the test (PI. 3, fig. 1a, d). Although this is almost certainly a gerontic feature in megalospheric forms, it occurs at an earlier stage in the microspheric generation of some subreticulate species. In these species it is accompanied by the formation of blister-like lateral chamberlets, the occurrence of which was noted by Smout (1954: 76). However, he regarded the secondary filaments as partitions of the alar prolongations whereas they are the distal walls of irregular chamberlets, all of which once formed part of the leading edge of the test (see Pl. 3, figs. 1d, e, 3a, b). It is not clear how the last few whorls of the test grew in species which lost their marginal cords in the last growth stage (e.g. $N$. obtusus), but it must presumably have been from extrusions of cytoplasm from pores along the leading edge (edges when there was more than one growth centre) or from trabecular pores which were present all over the test (including the peripheral margin).

\section{SEPTAL FILAMENTS IN THE N. BRITANNICUS GROUP}

The internal structures of the early, middle and late growth stages of one microspheric individual of $N$. britannicus are illustrated on PI. 2, figs. 1-4. The juvenile stage ( $\mathrm{Pl} .2$, fig. 1) possesses primary septal filaments and few, if any, secondary filaments, and therefore resembles a striate species. As the test increases in size, the upper part of the spiral cavity becomes partially isolated from the alar prolongations. In the outer whorls, the lower edge of each septum sweeps backwards on meeting the marginal cord of the previous whorl and forms a funnel-like constriction at the proximal end of the chamber lumen where it approaches the previous septum (Pl. 2, fig. 4). Each septum gives rise to a primary septal filament (= septal prolongation of Carpenter. 1849) at the point where it touches the marginal cord of the previous whorl (PI. 2. fig. 4). In the middle whorls of the test, the pattern of septal filaments is easy to discern since (in broken specimens) it can be seen to consist of primary filaments and secondary filaments which form the walls of the blister-like lateral chamberlets. Primary filaments may be thinner than the septa themselves, but they become irregularly thickened when granules are present. The filament pattern attains its maximum complexity in the adult stage when growth over the lateral surfaces is very largely effected by blister-like chamberlets which combine to produce a wavy leading edge. Simple buckling of the primary filaments, often associated with the presence of pillars, may have a similar effect. In $N$. brongniarti, the generally accepted end member of the $N$. laevigatus lineage, the filaments are often reduced to short, largely disconnected bars associated with granules. These give the latter whorls a subreticulate appearance but do not, in the adult stage at least. subdivide the spiral cavity into discrete chamberlets as in $N$. laevigatus and $N$. britannicus (see below).

In adult microspheric individuals of $N$. britannicus and its relatives, the terminal face of the shell is no longer the simple plane or curved surface seen in most planispirally coiled foraminifera, but an irregular. wavy

\section{Explanation of Plate 3}

Figs. 1a-e. N. britannicus Hantken. Megalospheric individual from the Middle Eocene of The Park, Selsey, Sussex: fig. 1a, lateral view $(\times 10)$ showing the irregular leading edge (arrowed) and the last few chambers, all of which are evolute; fig. $1 \mathrm{~b}$, c, edge view and terminal face $(\times 10$ and $\times 300)$ showing pores and grooves on the marginal cord and the absence of a primary aperture; fig. 1d, same individual tilted to show the irregular leading edge $(\times 60)$. Note limbate nature of septal traces in places; fig. 1e, enlargement $(\times 28)$ of rectangle marked on $1 \mathrm{~d}$ to show perforate lateral walls and coarse pores (leading into canals?) in otherwise imperforate leading edge. P52173.

Fig. 2. $N$. variolarius (Lamarck). Edge view showing chevron-shaped terminal face $(\times 60)$. Middle Eocene, Whitecliff Bay, Isle of Wight. P52174.

Figs. 3a, b. N. britannicus Hantken. B form, fig. 3a, mature individual showing leading edge (arrowed) made up of numerous chamberlets; fig. $3 \mathrm{~b}$, enlargement of rectangle to show blister-like lateral chamberlets. Fisher Bed 6 , Bracklesham, Sussex. P52175.

Fig. 4. N. britannicus Hantken. Fragment of microspheric shell showing canaliculate secondary septal filaments bounding irregular lateral chamberlets (roofs removed) $(\times 150)$. Note absence of regular communicating channels and pores. Middle Eocene. Bracklesham Bay, Sussex. P52176. 


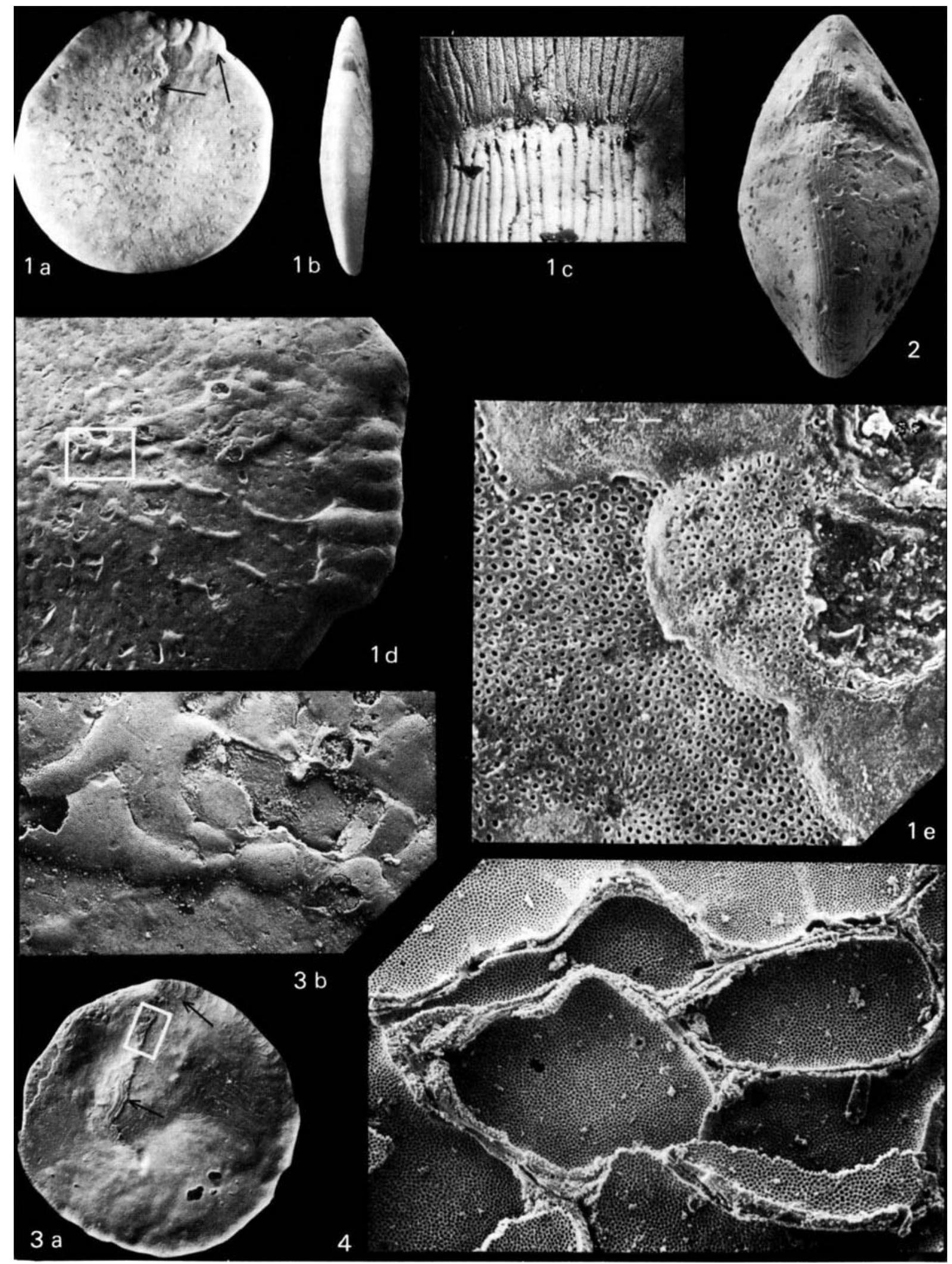


leading edge, formed by numerous septal filaments (PI. 3 , figs. 1a, d, e) not all of which were necessarily produced at the same time.

Secondary septal filaments are produced by nonuniform growth of the leading edge of the shell. All primary and secondary filaments form part of the leading edge (see Pl. 3, fig. 3a) when first formed, and although they later appear to subdivide the alar prolongations into chamberlets, this is an illusion. When lateral chamberlets form (as in $N$ britannicus, (Pl. 3, figs. 3, 4), true alar prolongations effectively disappear.

It seems probable that the cytoplasm necessary for the formation of lateral chamberlets issued either from trabecular pores on the underlying surface (Pl. 1, fig. 8) or from pores along the otherwise imperforate margin
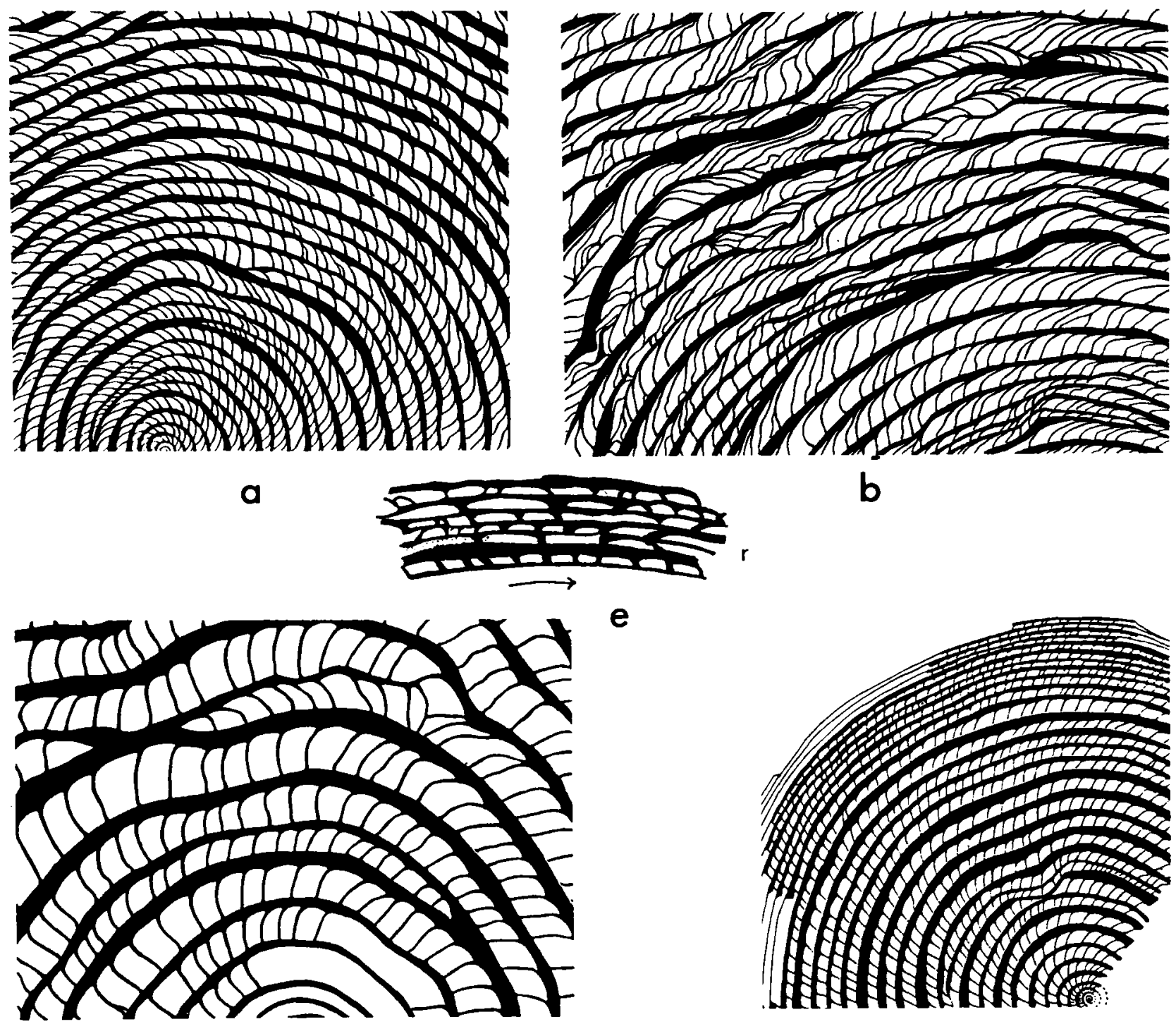

C

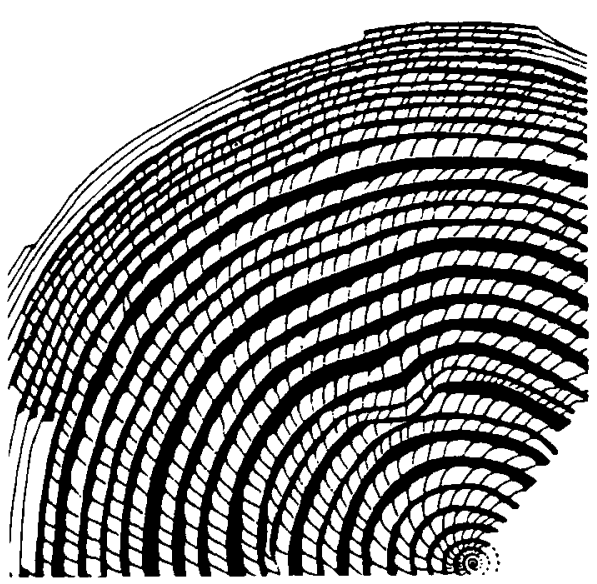

d

Fig. 6a-e. Coiling in Nummulites and Assilina (a-d from Schaub, 1981): a, N. millecaput showing normal intercalary whorls $(\times 5) ; \mathrm{b}, N$. maximus showing normal and reversed intercalary whorls $(\times 5) ; \mathrm{c}, A$. gigantea showing normal and reversed intercalary whorls $(\times 5)$. In this individual the reversed coil is short and is quickly over-ridden by a normal whorl $(\times 5)$;,$N$. obtusus showing tripartite spire and normal growth (origin of intercalary whorls not seen in this part of section) $(\times 5)$; e, outermost whorls of $N$. obtusus showing irregular interfilamental spaces and a short, false reversed coil $(r)$. Direction of growth indicated by arrow $(\times 15)$ (approx.). Samanta Collection, Lakhpat, Cutch. 
of the leading edge ( $\mathrm{Pl} .3$, fig. 1e). Passages between the lateral chamberlets themselves appear to be few and to lack any regular arrangement.

The most advanced members of the $N$. laevigatus group, $N$. puschi d'Archiac and $N$. brongniarti d'Archiac \& Haime, have rather unusual filaments. In $N$. puschi, the primary and secondary filaments are sinuous to strongly looped, and are truly filamentous (see Schaub, 1981, pl. 61, fig. 12); N. brongniarti, however, has a highly granulate surface which largely obscures any filaments that may be present, although vestiges of these can sometimes be seen over the chambers of the penultimate whorl. Examination of the outer whorls shows that a series of subradial striations extends from the marginal cord over the outer surface of each chamber (Pl. 4, fig. 1b). These are not septal filaments, but canaliculate granulose bars which seem to originate from the marginal cord itself (PI. 4, figs. 10, 11). As new whorls are added, the granules develop into discrete pillars which diverge as they extend upwards from their points of origin. The original striate appearance is therefore lost.

\section{SEPTAL FILAMENTS IN THE N. FICHTELI GROUP}

Lack of suitable material has made it difficult to add greatly to existing knowledge of the reticulate species. The following comments are, therefore, based largely on previous work.

The reticulum observed in members of the $N$. fabianii/N. fichteli lineage is not always formed entirely by septal filaments. In N. fabianii (see Boussac, 1906b; Roveda, 1970), it is produced by the intersection of primary septal filaments with a spiral ridge which develops along the lower outside edge of the marginal cord and appears as a series of regular pillars in transverse sections (Figs. 5a, b). This ridge becomes discontinuous and granulose in some individuals. Boussac $(1906 \mathrm{a}, \mathrm{b})$ recognised two stages in the development of the reticulum. Stage 1, a "mixed" network in which the spiral wall (ridge), granules and primary septal filaments all play a part (this is usually visible in the early stage of growth and is best seen in megalospheric forms of $N$. fabianii); stage 2, a "pure" network composed only of septal filaments. Both stages can be seen in the development of a single microspheric individual of $N$. fabianii. Boussac's pl. 1, figs. 1 and 2 (1906b) and Roveda's text-figs. 70-78 (1970), show clearly that the reticulum in the early stage of the megalospheric generation of $N$. fabianii is formed differently from that in $N$. laevigatus and its relatives. Mature microspheric (and occasionally also megalospheric) forms of $N$. fabianii and $N$. fichteli from European localities often show a very loose reticulation formed largely from primary and tertiary filaments (Pl. 4 , figs. 4,5 ); secondary filaments may be few. Later members of the $N$. fichteli group are very strongly reticulate, with third order filaments especially numerous and well developed. In these highly reticulate Oligocene representatives of the group (referred by Schaub, 1981, to N. sublaevigatus d'Archiac \& Haime) it is often impossible to distinguish primary and secondary filaments.

\section{CONCLUSIONS}

Three orders of septal filaments can be recognised in Nummulites.

1. Primary filaments which arise directly from the septa and are present in all species, although they may be difficult to distinguish and impossible to trace in some advanced reticulate forms.

2. Secondary filaments, which are merely the distal walls of blister-like chamberlets, develop ahead of, and finally almost completely replace, primary filaments; these are largely restricted to the subreticulate and reticulate groups.

3. Tertiary filaments which originate as spiral ridges or spirally arranged granules along the line of the marginal cord in primitive species, or as lateral spurs on either primary or secondary filaments. All are clearly canaliculate.

The three orders of septal filament should be distinguished both from each other and from septa and septal traces, since they are of taxonomic and biostratigraphic value. Primary filaments occur in all nummulites irrespective of group or age; secondary filaments and lateral chamberlets are found only in nummulites of Early to Middle Eocene age; tertiary filaments occur only in Late Eocene to Middle Oligocene species.

\section{GLOSSARY}

The following alphabetically arranged redefinitions of some primary morphological terms are based on those given by Davies (1935), amended and amplified where necessary from new observations. Equivalent French terms are given, where appropriate, in an attempt to avoid further confusion.

ALAR PROLONGATION. A lateral extension of the chamber cavity over the surface of the test.

FILAMENT TRACE. The surface expression of a septal filament on the spiral sheet.

LATERAL CHAMBERLET. Irregular, usually blister-like, small, secondarily formed chamber on the lateral surface of the test. Occurs in subreticulate species. The small cells produced by the development of tertiary filaments in reticulate species may also be regarded as lateral chamberlets although they form differently.

SEPTAL FILAMENT (Fr., filet cloisonnaire). Extension, sometimes thread-like, of a septum over the lateral surface of the test between the spiral laminae. Primary filaments are derived directly from the septa; secondary filaments arise from primary filaments; 
tertiary filaments arise from both primary and secondary filaments.

SEPTAL TRACE (Fr., filet cloisonnaire or filet). Surface expression of a septum on the outer surface of the spiral lamina. Homologous with chamber suture in other coiled foraminifera. Many authors have failed to distinguish between septal trace, septal filament trace and septal filament, and this has been a cause of confusion in the past.

Septa and septal traces are common to all chambered, calcareous foraminifera. Primary filaments are present in all species of Nummulites but may not be clearly distinguishable in advanced reticulate forms; secondary filaments are not present in simple, striate nummulites, and tertiary filaments occur only in advanced reticulate species.

Septal filaments and septal traces may be:-

i. RADIAL: straight or slightly curved, extending from the pole to the periphery. All septal filaments (and septa) are necessarily slightly curved at the peripheral margin.

ii. SIGMOIDAL. curved forwards at the periphery and backwards near the pole. If there is no polar twist, the shape is described as falciform.

iii. MEANDRINE: appearing to wander haphazardly over the surface of the spiral wall or within the spiral cavity. A misleading, and, as Davies (1935) noted, "inappropriate term", introduced before it was realised that the meandrine appearance is usually an artefact resulting from observations of abraded tests with closely appressed whorls.

iv. SUBRETICULATE: uniting to form a crude network within the spiral cavity, and showing as septal and filament traces on the outer surface of the spiral wall. Usually associated with pillars. v. RETICULATE: forming a complex network of filaments in which the individuality of the primary filaments is largely or completely lost. In primitive reticulate species such as $N$. fabianii, the reticulum is not wholly composed of filaments but of filaments plus a spiral ridge produced by thickening of the marginal cord.

SEPTAL FILAMENT NETWORK or RETICULUM (Fr. Réseau cloisonnaire). A net-like structure composed largely of secondary and tertiary filaments.

SEPTUM (Fr. cloison). A bilamellar, canaliculate, but primarily apertureless curved plate (partition) between successive chambers. Basally situated secondary foramina are almost invariably visible in accurately orientated equatorial sections. Other secondary pores may also be present, especially near the peripheral margin. SPIRAL CAVITY. The total space between the whorls of the spiral lamina. It is subdivided by septa and septal filaments.

\section{ACKNOWLEDGEMENTS}

I wish to thank Prof. Dennis Curry (lately of University College, London), Prof. John R. Haynes (University College, Aberystwyth) and Dr. Bimal K. Samanta (University of Calcutta) for reading and constructively criticising the typescript; their helpful observations have been incorporated wherever possible. I am also glad to acknowledge the useful suggestions made by the Society's referee. My colleague, Dr. John E. Whittaker, kindly assisted by taking the SEM photographs and improving the plates. Mr. R. L. Hodgkinson prepared the material and assisted during all stages of the work; his invaluable help is gratefully acknowledged.

\section{Explanation of Plate 4}

Figs. 1a, b. $N$. brongniarti d'Archiac \& Haime. Microspheric form broken open and dissected to show septa, marginal cord, "septal" filaments and subradiate ridges: fig. $1 \mathrm{a} \times 4$, fig. $1 \mathrm{~b} \times 34$. Middle Eocene, Ronca, Verona, Italy. P52177. See figs. 10, 11 for explanation of white lines. Arrows indicate subradiate ridges.

Figs. 2, 3. N. planulatus Lamarck. Lateral views showing failure of some primary filaments to reach the centre. In fig. 3 a secondary, off-centre node has formed: fig. $2 \times 10$; fig. $3 \times 5$. Early Eocene, Aizy-Jouy, Paris Basin. P52178 and P52179.

Fig. 4. N. fabianii Prever. Microspheric form showing traces of "septal filaments", some extending towards the marginal cord $(\times 8)$. Upper Eocene, Priabona, Italy. P52180.

Fig. 5. N. fichteli (Michelotti). Megalospheric form; abraded lateral surface showing secondary and tertiary septal filaments $(\times 16)$. Oligocene, France. Locality uncertain. P52181.

Figs. 6, 7. N. gizehensis Fơrskal. Abraded surfaces showing "complex" filament patterns. P52182 and P52183.

Figs. 8, 9. N. obtusus (Sowerby): fig. 8, (syntype), half section showing loss of marginal cord in the last few whorls $(\times 8), 46223$; fig. 9, edge view of individual showing septal filaments extending over the periphery in the absence of the marginal cord. Note presence of trabeculae $(\times 10)$. Harudi Formation, Lakhpat, Cutch (Samanta Collection). P52184.

Figs. 10, 11. N. brongniarti d'Archiac \& Haime. Thin sections $(\times 17)$ through marginal cord (fig. 10) and lumen of chamber in last whorl (fig. 11) to show the pillar-like appearance of the subradiate ridges just visible in fig. $1 \mathrm{~b}$ (above). Solid white line in 1b marks plane of section in fig. 10; broken white line marks plane of fig. 11. Middle Eocene, Ronca, Italy. P52185 and 5a. 


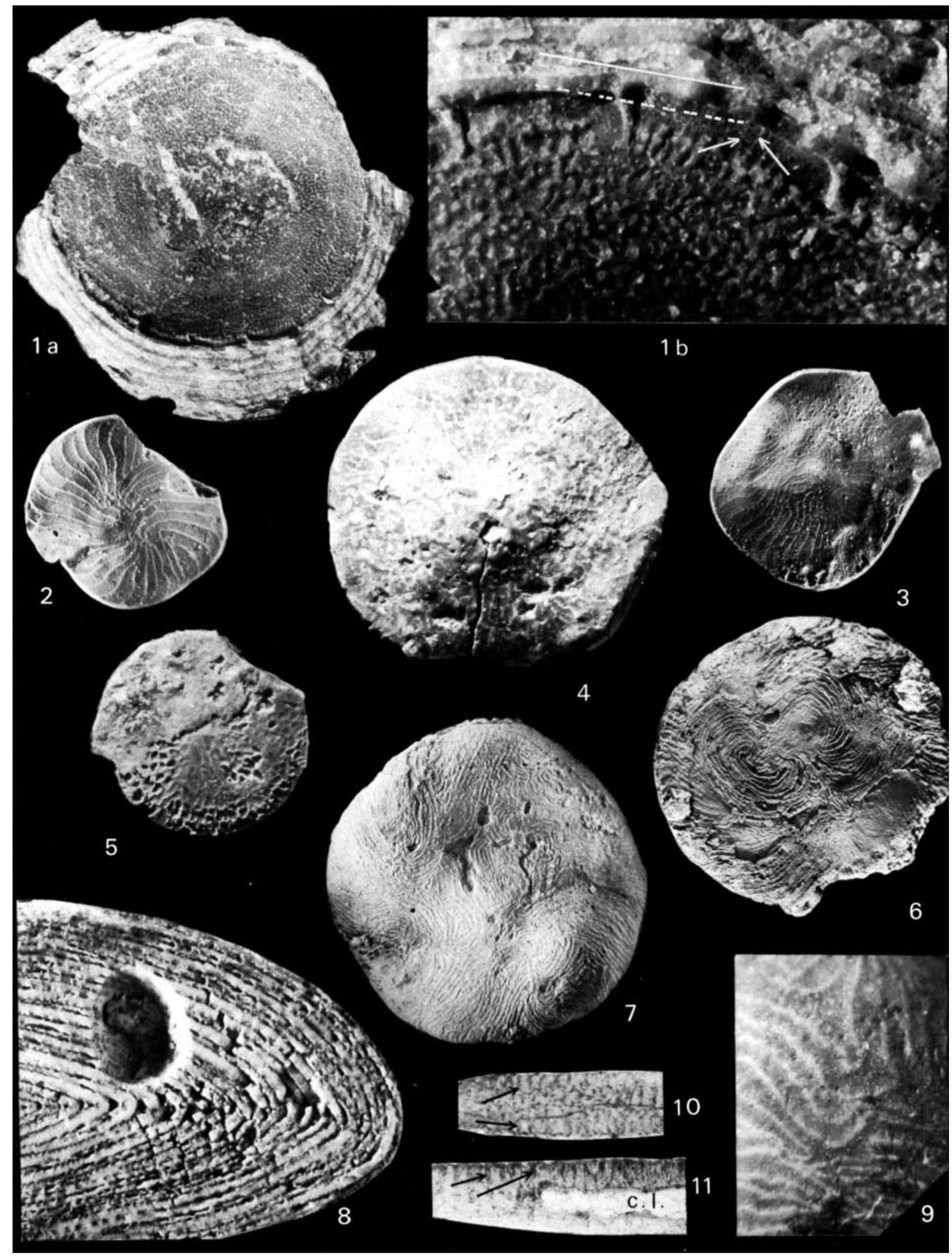




\section{Manuscript received June 1987. Revised manuscript accepted December 1987.}

\section{REFERENCES}

Archiac, A. d' \& Haime, J. 1853. Description des Animaux Fossiles du Groupe Nummulitique de l'Inde. Précédée d'un résumé géologique et d'une monographie des Nummulites. Gide et J. Baudry, Paris. 223 pp.

Blondeau, A. 1972. Les Nummulites. Paris, Librairie Vuibert, 254 pp., 38 pls.

Boussac, J. 1906a. Sur la formation du réseau des Nummulites réticulées. C.r. Séanc. Acad. Sci., 142 (4), 243-4.

Boussac, J. 1906b. Sur la formation du réseau des Nummulites réticulees. Bull. Soc. géol. Fr., 4th ser., 6, 98-100.

Boussac, J. 1911. Etudes paléontologiques sur le Nummulitique alpin. Mém. Explic. Carte géol. dét. France, 1-439 (texte), atlas: pl. I-XXII.

Carpenter, W. B. 1849. On the microscopic structure of Nummulina, Orbitolites and Orbitoides. Proc. geol. Soc., London, 6, 21-38, pls. 3-8.

Davies, A. M. 1935. Tertiary Faunas. Vol. 1. The composition of Tertiary faunas. (2nd ed.). George Allen \& Unwin. London, $571 \mathrm{pp}$.

Hottinger, L. 1977. Foraminifères operculiniformes. Mém. Mus. Hist. nat. Paris, Sér. C, XL, 159 pp., 66 pls.

Röttger, R., Spindler, M., Schmaljohann, R., Richwien, M. \& Fladung, M. 1984. Functions of the canal system in the rotaliid foraminifer Heterostegina depressa. Nature, London, 309, 789-791.

Roveda, V. 1970. Revision of the Nummulites (Foraminiferida) of the $N$. fabianii-N. fichteli group. Riv. Ital. Paleont., 76 (2), 235-324, pls. 22-25.

Rozlozsnik, P. 1927. Einleitung in das studium der Nummulinen und Assilinen. Mit. Jb. K. ung. geol. Anst., XXVI (1), 1-154, pl. 1.

Rozlozsinik, P. 1929. Studien über Nummulinen. Geologica hung., Ser. Paléont., 2, 1-164, pls 1-8.

Samanta, B.K. 1981. Two stratigraphically important Nummulites species from the Middle Eocene of India and Europe. Palaeontology, London, 24 (4), 803-826.

Schaub, H. 1981. Nummulites et Assilines de la Téthys paléogène. Taxinomie, phylogenèse et biostratigraphie. Mém. suisses Paléont., 104-106, 238 pp., 18 pls.

Smout, A. H. 1954. Lower Tertiary foraminifera of the Qatar Peninsula. Monog. Br. Mus. (nat. Hist.), London, i-ix + 96 pp., 15 pls. 